\title{
The Effect of Infection With Genital Mycoplasma hominis and the Presence of Antisperm Antibodies in Iranian Women With Unexplained Infertility
}

\author{
Mana Talebi Farahani ${ }^{1}$, Farzaneh Hoseini ${ }^{1 *}$, Arash Minai-Tehrani ${ }^{2}$, Marefat Ghafari Novin ${ }^{3}$
}

\begin{abstract}
Objectives: Mycoplasma hominis (M. hominis) infection is considered as one of the most common sexually transmitted diseases. Antibodies against sperm can influence fertilization through different mechanisms. These two factors can affect women's fertility status. Therefore, this study was conducted to evaluate the relationship between infection with genital M. hominis and the presence of antisperm antibodies (ASA).

Materials and Methods: Case-control study was conducted using 50 patients with primary or secondary infertility as a case group and 50 healthy women as a control group in Sarem's women hospital. DNA was extracted from urine samples and the presence of M. hominis (past infection) was determined by PCR. In addition, the presence of antibody against $M$. hominis in the serum (current infection) was assessed by ELISA. On the other hand, the presence of ASA was further evaluated by IgG-MAR test in the serum. Results: Our results clearly demonstrated that the prevalence of $M$. hominis (evaluated by PCR) in the two groups was not significantly different. Furthermore, the presence of antibodies against $M$. hominis and sperm was not significantly different as compared between fertile and infertile women.

Conclusion: The current study demonstrated that there is no distinct association between current or past infection with M. hominis and the levels of antisperm antibody in women with unexplained infertility. This result can be due to limitation in antiserum used in IgG-MAR test to recognize all ASA in serum of infertile women.

Keywords: Antisperm antibody, Infertility, Mycoplasma hominis
\end{abstract}

\section{Introduction}

Mycoplasma hominis ( $M$. hominis), a gram-negative intracellular bacterium, belongs to the Mycoplasmataceae family in the Mollicutes class $(1,2)$. It consists of pleomorphic filaments with an average diameter of 0.1 to 0.3 micrometers and can pass through the most used bacteriological filters $(0.45 \mu \mathrm{m})$. These bacteria multiply by binary division and contain RNA and DNA (3) and have a symbiotic relationship with Trichomonas vaginalis (2). It has been reported that $M$. hominis can be associated with pelvic inflammatory disease causing ectopic pregnancy. These bacteria and other gram-negative bacteria are involved in the development of bacterial vaginosis that may be one of the causes of premature birth and abortion $(1,4)$. Pregnant women with bacterial vaginosis may be at risk for premature rupture of membranes, premature birth, chorioamnionitis, endometritis after cesarean section and spontaneous abortion. The risk of premature birth and miscarriage is increased up to 5 and 5.5 times in women with bacterial vaginosis (5).

Sperm has long been known to have antigenic properties (6). Antisperm antibodies (ASA) are detected in 9\% to $12.8 \%$ of infertile couples $(7,8)$. These antibodies are also observed in approximately $1 \%-2.5 \%(9,10)$ and $1.4 \%$ of fertile men and women, respectively (11). In addition, ASA can be detected in blood, genital fluids such as seminal plasma, cervical mucus and follicular fluid (12). Several studies show that same value of ASA is present in follicular fluid of women with high blood ASA. ASA in follicular fluid originates from the blood and contains high levels of IgG and IgA, while IgM due to high molecular weight, cannot be seen at high level (13).

Due to the influence of religious beliefs on sexual intercourse, prevalence of sexually transmitted infections and their association with important parameters such as ASA may vary. Therefore, this study aimed to determine the prevalence of $M$. hominis, the presence of ASA and the relationship between $M$. hominis antibody (IgG) with ASA, to evaluate the association between $M$. hominis infection and ASA in women with unexplained infertility.

\section{Materials and Methods}

This study was a case-control study and conducted on women with unexplained infertility visiting Sarem hospi- 
tal. Fifty married women with unexplained infertility, aged between 23-39 were considered as a case group; while 50 healthy women aged 26-47 years (at least with one normal pregnancy) were regarded as a control group. Members of both groups did not show any genital tract infection, and none of the women had received antibiotics or corticosteroids at least for 15 days before samples were taken.

Furthermore, all female patients were normal regarding the uterus and fallopian tubes status (assessed by laparoscopy or hystrosalpingography), hormonal factors, ovarian related tests, thyroid and adrenal gland function. The male partners of these women were normozoospermia. The blood samples were taken from women and centrifuged $(3000 \mathrm{rpm})$ at room temperature for 10 minutes to separate serum, and then kept in at $-20^{\circ} \mathrm{C}$ until further analysis.

Approximately $15-30 \mathrm{ml}$ of urine samples were collected in sterile containers and incubated at $2^{\circ} \mathrm{C}-8^{\circ} \mathrm{C}$ as overnight and then $10-30 \mathrm{ml}$ of the supernatant was centrifuged. The obtained pellets were kept at $-20^{\circ} \mathrm{C}$ for further experiments; it can be used for DNA extraction within two months.

Immunoassay Detection of Mycoplasma hominis

The antibodies in both groups were measured using indirect ELISA kit (Euroimmun IgG indirect immunofluorescence test Mycoplasma, ELISA EUROIMMUN, New Jersey, USA) according to manufacturer's instruction. The slides were observed under a microscope with black background and a magnification of 400. All objects reflecting green light were considered positive, while the objects reflecting red light were negative.

Molecular Detection of Mycoplasma hominis in Urine The extraction of bacterial DNA from the urine of patients was carried out according to manufacture instruction (QIAGEN DNA Mini Kit Qiagen, Hilden, Germany). And the PCR for M. hominis was performed using DNA-Technology kit (DNA-Technology Research and Production Company, ZAO, Russia). The PCR conditions are shown in Table 1 . The PCR products were loaded in $2 \%$ agarose gels and stained with ethidium bromide $(0.1 \%)$.

Mixed Agglutination Reaction Test-IgG Class (MAR Test) The test was performed according to the manufacture instruction (FertiPro MAR test, Fertipro, Beernem, Belgium). In summary, serum, after thawing, were inactivated for 30 minutes at $56^{\circ} \mathrm{C}$ water bath and then diluted at a ratio of 1 to 16 with Ham's F10 without albumin. Results are expressed as the percentage of agglutinated sperm (0\%-10\% negative, $10 \%-40 \%$ suspected and above $40 \%$ positive). Results were analyzed by chi-square test in SPSS software. $P<0.05$ was considered statistically significant.

\section{Results}

In this study, the urine and serum samples of 50 women with unexplained infertility (primary infertility $n=37$ and secondary infertility $n=13$ ) and 50 healthy women were investigated. The average age of the infertile and control groups was (35.58 \pm 5.17 years) and $(32.34 \pm 3.74$ years) respectively, and did not show any statistically significant difference $(P>0.05)$.

The prevalence of antibody against $M$. hominis $(\operatorname{IgG})$ in infertile women and in the control group did not represent statistically significant difference as shown in the Table $2(P=0.13)$.

Furthermore, as shown in Table 3, the prevalence of antibody against $M$. hominis in primary and secondary infertile women did not show significant difference $(P=0.58)$. The electrophoresis results of PCR products for M. hominis gene are shown in Figure 1.

In general, there was no one having $M$. hominis as determined by PCR in both groups. The prevalence of ASA in infertile and fertile women did not show any significant difference (Table 4; $P=0.31$ ).

On the other hand, the prevalence of ASA in current or

Table 1. Thermal Profile for the PCR Amplification

\begin{tabular}{lccc}
\hline Name & $\begin{array}{r}\text { Temperature } \\
\left({ }^{\circ} \mathbf{C}\right)\end{array}$ & $\begin{array}{c}\text { Incubation Time } \\
\text { (Seconds) }\end{array}$ & Cycles \\
\hline Pre-denaturation & 94 & 90 & \\
Denaturation-1 & 94 & 50 & $\mathbf{5}$ \\
Annealing-1 & 62 & 50 & \\
Elongation-1 & 72 & 50 & \\
Denaturation-2 & 94 & 50 & $\mathbf{4 0}$ \\
Annealing-2 & 64 & 50 & \\
Elongation-2 & 72 & 50 & \\
\hline
\end{tabular}

Table 2. Prevalence of Anti-Mycoplasma hominis (IgG) in Serum of Cases and Control

\begin{tabular}{llccc}
\hline & & \multicolumn{2}{c}{ Anti-Mycoplasma hominis } & \multirow{2}{*}{ Total } \\
\cline { 3 - 4 } & & $+(\%)$ & $-(\%)$ & \\
\hline \multirow{2}{*}{ Groups } & Case & $9(18)$ & $41(82)$ & 50 \\
\cline { 3 - 4 } Total & Control & $4(8)$ & $46(92)$ & 50 \\
\hline
\end{tabular}

Table 3. Prevalence of Anti-Mycoplasma hominis ( $\operatorname{lgG}$ ) in Primary and Secondary Infertility Patients

\begin{tabular}{lcccc}
\hline & & \multicolumn{2}{c}{ Groups } & \multirow{2}{*}{ Total } \\
\cline { 3 - 4 } & & Primary & Secondary & \\
\hline \multirow{2}{*}{ Groups } & $(+)$ & $6(16.2)$ & $3(23.1)$ & 9 \\
& $(-)$ & $31(83.8)$ & $10(76.9)$ & 41 \\
\multirow{3}{*}{ Total } & & 37 & 13 & 50 \\
\hline
\end{tabular}

Table 4. Prevalence of ASA in Fertile and Infertile Women

\begin{tabular}{lcccc}
\hline & & \multicolumn{2}{c}{ Groups } & Total \\
\cline { 3 - 4 } & & Case (\%) & Control (\%) & \\
\hline \multirow{2}{*}{ ASA } & $(+)$ & $0(0)$ & $1(2)$ & 1 \\
& $(-)$ & $50(100)$ & $49(98)$ & 99 \\
Total & & 50 & 50 & 100 \\
\hline
\end{tabular}

Abbreviation: ASA, antisperm antibodies. 


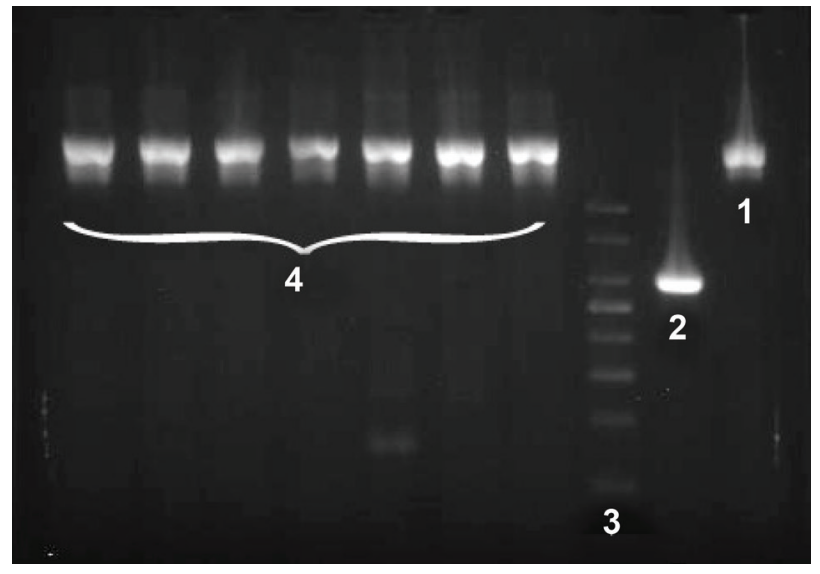

Figure 1. The Electrophoresis Results of PCR Products for Mycoplasma hominis on 2\% Agarose Gel. 1; negative control, 2; positive control: $310 \mathrm{bp}$ band, 3; DNA ladder, 4: the patients with negative results.

Table 5. Relationship Between ASA and Mycoplasma hominis Infection

\begin{tabular}{ccccc}
\hline & & \multicolumn{2}{c}{ Anti-Mycoplasma hominis } & \multirow{2}{*}{ Total } \\
\cline { 3 - 4 } & & $+(\%)$ & $-(\%)$ & \\
\hline \multirow{2}{*}{ ASA } & $(+)$ & $0(0)$ & $1(1.1)$ & 1 \\
\multirow{2}{*}{ Total } & $(-)$ & $13(100)$ & $86(98.9)$ & 99 \\
\hline
\end{tabular}

Abbreviation: ASA, antisperm antibodies.

past infection with $M$. hominis of fertile and infertile did not show any statistically significant difference $(P=0.69)$ which indicated that there is no distinct association between the presence of ASA and current or past infection with $M$. hominis in serum and urine of investigated women (Table 5).

\section{Discussion}

M. hominis is the most common bacterial cause of sexually transmitted infections. The immune response of the host and genetic predisposition play vital role in pathogenesis of long-term complications following infection (14). It is very crucial to realize why and how some of the women produce ASA and how the immune system causes their infertility. However, the aspects that influence the production of ASA in some women are not well addressed. Besides, the reason why most women do not develop an immune response upon exposure to sperm is not well understood (15-17). This case-control study was carried out to study the relationship between past (detected by PCR) and current Mycoplasma infection (determined Indirect ELISA) and ASA in asymptomatic women with primary or secondary infertility, aiming to determine the association between Mycoplasma infection and produced ASA in women that has not yet been well understood. Previous studies have shown that the prevalence of $M$. hominis in Iranian women is between $16 \%-40 \%$ depending on the measurement method (18-23). In this study, the prevalence of current infection with $M$. hominis in as- ymptomatic infertile women and control was $18 \%$ and $8 \%$ respectively, while, the prevalence of past infection with $M$. hominis, in fertile and infertile women was $0 \%$. In the Unites States, the prevalence of infection with $M$. hominis was $1.3 \%$ and in Poland (determined by biochemical method) was $3.7 \%$ indicating that the prevalence of infection was lower as compared with Iran regarding to the present study $(24,25)$.

Najar Peerayeh et al (23) and Vatani (5) showed that prevalence of Mycoplasma in infertile women was $16 \%$ and 13.3 $\%$ respectively, indicating higher prevalence as compared with the present study. In our study, the prevalence of ASA was $0 \%$ and $2 \%$ in infertile and fertile women, respectively. In several other studies, different results were obtained in comparison with the present study. Haas et al (26) reported that $13 \%$ of women were positive for ASA. Witkin showed that the prevalence of anti-sperm antibodies was $15 \%$ as determined by ELISA (27), while in another study conducted by Mandelbaum et al (28) 15\% of women had ASA against sperm head proteins.

Here, the prevalence of antibodies against $M$. hominis for $M$. hominis current infection did not show a significant difference between fertile and infertile women. In addition, the prevalence of past and current infection with $\mathrm{My}$ coplasma did not show statistically significant difference between the primary and secondary infertile women. This is not accepted that risk factors for mycoplasma infections is only limited to the duration of active sexual behavior, while, having multiple partners can be more effective (29). Low prevalence of $M$. hominis in the present study is consistent with the other studies indicating 3\%-8.7\% in infertile women without any symptoms. One explanation for these variations in the prevalence can be the differences in the study population, applied methods, infection of male partner or the other causes of infertility in different studies (30).

No association between current or past infection with Mycoplasma and unexplained infertility was found in the present study. In contrast, previous studies have been reported a positive correlation between past infection with M. hominis and subfertility $(14,31,32)$. Exposure to Mycoplasma heat shock proteins, can significantly affect mucosal immune system by the release of cytokines (IFN-A, IL-10 and TNF-A) leading to severe immunopathological conditions associated with infertility. These results are observed in infertile women with infection while such an issue has not been reported in infected fertile women $(33,34)$. This may be due to differences in the types of infertility in women (women with unexplained infertility in comparison with subfertile women in this study).

\section{Conclusion}

This study did not find any significant correlation between current or past infection in women with M. hominis and unexplained infertility. In addition, there was no significant relationship among current or past infection with M. hominis and ASA. This may show that M. hominis infection could not induce ASA production. In addition, 
these results can be due to the absence of ASA in antiserum used in IgG MAR test to recognize all ASA in serum of infertile women. Evaluation of relationship between infections with other sexual transmitted bacteria and ASA is recommended.

\section{Ethical issues}

The Ethics Committee of Molecular and Cellular Research Center of Sarem hospital approved the study and written informed consent was also obtained from all mentioned women.

\section{Conflict of interests}

None to be declared.

\section{Financial support}

This research was approved and supported by Islamic Azad University, North Tehran Branch in June 2012.

\section{Acknowledgments}

The authors would like to thank Dr. Aboutaleb Saremi, Dr. Pirooz Salehian, Shiva Hasani, Elham Savadi-Shiraz, Pegah Hamzelou, and Shadi Tavakkoli for their collaboration in this research.

\section{References}

1. Pitcher DG, Nicholas RAJ. Mycoplasma host specificity: Fact or fiction? Veterinary J. 2005;170(3):300-306. doi: 10.1016/j.tvjl.2004.08.011.

2. Jensen JS. Mycoplasma genitalium infections. Danish Med Bull. 2006;53:1-27.

3. Waites KB. Mycoplasma and ureaplasma. Congenital Perianal Infections 2006;271-288. doi:10.1385/159259-965-6:271.

4. Taylor-Robinson D. The role of mycoplasmas in pregnancy outcome. Best Practice Res Clin Obstet Gynaecol. 2007;21(3):425-438. doi:10.1016/j. bpobgyn.2007.01.011.

5. Vatani S. Prevalence of genital Mycoplasmas in women with negative culture of bacterial vaginosis by polymerase chain reaction. Gorgan Univ Med J 2006;8(1):46. [Persian].

6. Chamley LW, Clarke GN. Antisperm antibodies and conception. SeminImmunopathol 2007;29(2):169-84. doi:10.1007/s00281-007-0075-2.

7. Ayvaliotis B, Bronson R, Rosenfeld D, Cooper G. Conception rates in couples where autoimmunity to sperm is detected. Fertile Steril. 1985;43(5):739-742.

8. Collins JA, Burrows EA, Yeo J, Young Lai EV. Frequency and predictive value of antisperm antibodies among infertile couples. Hum Reprod. 1993;8(4):592-598.

9. Ford WC, Williains KM, McLaughlin EA, Harrison S, Ray B, Hull MG. The indirect immunobead test for seminal antisperm antibodies and fertilization rates at in- vitro fertilization. Hum Reprod. 1996;11(7):14181422.

10. Heidenreich A, Bonfig R, Wilbert DM, Strohmaier
WL, Engelmann UH. Risk factors for antisperm antibodies in infertile men. Am J Reprod Immunol. 1994;31(3):69-76. doi:10.1111/j.1600-0897.1994. tb00849.x.

11. Clarke GN, Baker HW. Lack of association between sperm antibodies and recurrent spontaneous abortion. Fertil Steril. 1993;59(2):463-464.

12. Marin-Briggiler CI, Vazquez-Levin MH, GonzalezEcheverria F, Blaquier JA, Miranda PV, Tezon JG. Effect of antisperm antibodies present in human follicular fluid upon the acrosome reaction and sperm-zona pellucid interaction. Am J Reprod Immunol. 2003;50(3):209-19. doi:10.1034/j.16000897.2003.00082.x.

13. Clarke GN, Hsieh C, Koh SH, Cauchi MN. Sperm antibodies, and complement in human follicular fluid. Am J Reprod Immunol. 1984;5(4):179-181. doi:10.1111/j.1600-0897.1984.tb00192.x.

14. Bohring C, Krause W. Characterization of spermatozoa surface antigens by antisperm antibodies and its influence on acrosomal exocytosis. Am J Reprod Immunol. 2003;50(5):411-9. doi:10.1034/ j.1600-0897.2003.00103.x.

15. Hirano $Y$, Shibahara H, Koriyama J, Tokunaga M, Shimada K, Suzuki M. Incidence of spermimmobilizing antibodies in infertile women with past chlamydia trachomatis infection. Am J Reprod Immunol. 2011;65(2):375-434. doi:10.1111/j.16000897.2010.00883.x.

16. Malik A, Jain S, Rizvi M, Shukla I, Hakim S. Chlamydia trachomatis infection in women with secondary infertility. Fertil Steril. 2009;91(1):91-95. doi:10.1016/j.fertnstert.2007.05.070

17. Brunham RC, Pourbohloul B, Mak S, White $\mathrm{R}$, Rekart ML. The unexpected impact of a Chlamydia trachomatis infection control program on susceptibility to reinfection. J Infect Dis. 2005;192(10):1836-1844. doi:10.1086/497341.

18. Stellrecht KA, Woron AM, Mishrik NG, Venezia RA. Comparison of multiplex PCR assay with culture for detection of genital mycoplasmas. J Clin Microbiol. 2004;42(4):1528-33. doi:10.1128/JCM.42.4.15281533.2004.

19. Najar Peerayeh S, Sattari M. Detection of Ureaplasma urealyticum and Mycoplasma hominis in endocervical specimens from infertile women by polymerase chain reaction. Middle East Fertil Soc J. 2006;11(2):104-108.

20. Naderi Nasab M, Ghenaat J, Rashed T, Ghazvini K. Prevalence of serological anti Chlamydia trachomatis in patient with genital infection in Mashhad. Iran Univ Med Microbiol J. 2007;1(2):35-41. [Persian].

21. Chamani-Tabriz L, Tehrani MJ, Zeraati H, et al. A molecular survey of Chlamydia trachomatis infection in married women: a cross sectional study on 991 women. Tehran Univ Med J. 2008;66(7):485-491. [Persian].

22. Rashidi B, Chamani Tabriz L, Haghollahi F, et al. A 
molecular \& serological of Chlamydia trachomatis infection in fertile \& infertile women. J Reprod Infertil. 2009;10:32-41. [Persian].

23. Najar Peerayeh S, Aleyasin A. Comparison of PCR assay with culture for detection of Mycoplasma hominis in infertile women. Kowsar Med J 2005;10(3):183-90.

24. Imudia AN, Detti L, Puscheck EE, Yelian FD, Diamond MP. The prevalence of Ureaplasma urealyticum, Mycoplasma hominis, Chlamydia trachomatis and Neisseria gonorrhoeae infections and the rubella status of patients undergoing an initial infertility evaluation. J Assist Reprod Genet. 2008;25(1):43-46. doi:10.1007/s10815-007-9192-Z.

25. Zdrodowska-Stefanow B, Klosowska WM, Ostaszewska-Puchalska I, Bulhak-Koziol V, Kotowicz B. Ureaplasma urealyticum and Mycoplasma hominis infection in women with urogenital diseases. Adv Med Sci. 2006;51(1):250-253.

26. Haas GG Jr, Cines DB, Schreiber AD. Immunologic infertility: identification of patients with antisperm antibodies. N Engl J Med. 1980;303:722-7. doi: 10.1056/NEJM198009253031303

27. Witkin SS. Sperm-reactive antibodies as measured by enzyme linked immunosorbent assay. In: Mathur S, Fredicks CM, eds. Fundamentals of Immunoreproduction: Conception and Contraception. Washington: Hemisphere Publishing Company; 1988.

28. Mandelbaum SL, Diamond MP, DeCherney
AH. Relationship of antibodies to sperm head to etiology of infertility in patients undergoing in vitro fertilization/embryo transfer. Am J Reprod Immunol. 1989;19(1):3-5. doi:10.1111/j.1600-0897.1989. tb00539.x.

29. Awsare NS, Krishnan J, Boustead GB, Hanbury DC, McNicholas TA. Complications of vasectomy. Ann R Coll Surg Engl. 2005;87(6):406-410.

30. Mahmoud A, Comhaire F. Antisperm antibodies: use of the mixed agglutination reaction (MAR) test using latex beads. Hum Reprod. 2000;15(2):231-3. doi:10.1093/humrep/15.2.231.

31. Bohring C, Krause W. The role of antisperm antibodies during fertilization and for immunological infertility. Chem Immunol Allergy. 2005;88:15-26. doi:10.1159/000087818.

32. Guven MA, Dilek U, Pata O, Dilek S, Ciragil P. Prevalence of Chlamydia trochomatis, Ureaplasma urealyticum and Mycoplasma hominis infections in the unexplained infertile women. Arch Gynecol Obstet. 2007;276(3):219-223.

33. Chavez-Badiola A, Drakeley AJ, Finney V, Sajjad Y, Lewis-Jones DI. Necrospermia, antisperm antibodies, and vasectomy. Fertil Steril. 2008;89(3):723.e5-e7.

34. Günyeli I, Abike F, Dünder I, et al. Chlamydia, Mycoplasma and Ureaplasma infections in infertile couples and effects of these infections on fertility. Arch Gynecol Obstet. 2011;283(2):379-385. doi: 10.1007/s00404-010-1726-4.

Copyright $\odot 2016$ The Author(s); This is an open-access article distributed under the terms of the Creative Commons Attribution License (http://creativecommons.org/licenses/by/4.0), which permits unrestricted use, distribution, and reproduction in any medium, provided the original work is properly cited. 